BULLETIN OF THE

AMERICAN MATHEMATICAL SOCIETY

Volume 81, Number 1, January 1975

\title{
THE APRIL MEETING IN SANTA BARBARA
}

The seven hundred fourteenth meeting of the American Mathematical Society was held at the University of California, Santa Barbara, on Saturday. April 27, 1974. There were 94 registrants including 49 members of the Society.

Two invited hour addresses were given by invitation of the Committee to Select Hour Speakers for Far Western Sectional Meetings. Professor Garth W. Warner of the University of Washington gave a lecture entitled L-functions on reductive groups. He was introduced by Professor V.S. Varadarajan. Professor Hung-Hsi Wu of the University of California, Berkeley, lectured on Applications of some theorems in partial differential equations to geometry. He was introduced by Professor John Douglas Moore.

Professors Marvin Marcus, Henryk Minc, and Robert C. Thompson organized two special sessions of thirty-minute papers on Linear Algebra. The speakers were John DePillis, Eugene C. Johnsen, Herbert J. Ryser, Robert C. Thompson, Olga Taussky-Todd, and Stanley G. Williamson.

There were two sessions of contributed ten-minute papers. They were chaired by Professors Jack G. Ceder and Max L. Weiss.

Local arrangements were handled by Professor Stephen Simons.

EUGENE, OREGON

KENNETH A. Ross Associate Secretary

\section{THE MAY MEETING IN DEKALB}

The seven hundred fifteenth meeting of the American Mathematical Society was held at Northern Illinois University, DeKalb, Illinois, from Monday, May 13 to Friday, May 17, 1974. There were 288 registrants, including 237 members of the Society.

With the support of the National Science Foundation there was a symposium on Mathematical Developments arising from the Hilbert Problems, which ran from Monday through Thursday, May 13-16. This topic was chosen by the Committee to Select Hour Speakers for Western Sectional Meetings, which during 1973 consisted of Paul T. Bateman (chairman), Donald J. Lewis, and Daniel Zelinsky. The Organizing Committee of the Symposium, responsible for the planning of the program and 